\title{
Clinical utility of quantitative HBsAg in natural history and nucleos(t)ide analogue treatment of chronic hepatitis $B$ : new trick of old dog
}

\author{
Tai-Chung Tseng $\cdot$ Jia-Horng Kao
}

Received: 9 July 2012/ Accepted: 14 August 2012/Published online: 24 October 2012

(C) Springer 2012

\begin{abstract}
Using commercial quantitative assays, quantitative hepatitis B surface antigen (qHBsAg) has improved our understanding and management of chronic hepatitis $B$ (CHB). The HBsAg level is highest in the immune tolerance phase, starts to decline during the immune clearance phase, and decreases slowly but progressively after hepatitis B e antigen ( $\mathrm{HBeAg}$ ) seroconversion. The HBsAg level is lowest in individuals with an inactive carrier state but higher in those who develop HBeAg-negative hepatitis. It
\end{abstract}

Part of this review was presented at The 3rd International Forum of the 98th General Meeting of the Japanese Society of Gastroenterology.

T.-C. Tseng

Division of Gastroenterology, Department of Internal Medicine,

Buddhist Tzu Chi General Hospital,

Taipei Branch, Taipei, Taiwan

T.-C. Tseng · J.-H. Kao ( $\varangle)$

Graduate Institute of Clinical Medicine, National Taiwan

University College of Medicine, National Taiwan University

Hospital, 7 Chung-Shan South Road, Taipei 10002, Taiwan

e-mail:kaojh@ntu.edu.tw

T.-C. Tseng

School of Medicine, Tzu Chi University, Hualien, Taiwan

J.-H. Kao

Department of Internal Medicine, National Taiwan University College of Medicine, National Taiwan University Hospital,

Taipei, Taiwan

J.-H. Kao

Department of Medical Research, National Taiwan University College of Medicine, National Taiwan University Hospital,

Taipei, Taiwan

J.-H. Kao

Hepatitis Research Center, National Taiwan University College of Medicine, National Taiwan University Hospital,

Taipei, Taiwan has been shown that a reduction of HBsAg by $1 \log \mathrm{IU} / \mathrm{mL}$ or more reflects improved host immune control of HBV infection. A combination of $\mathrm{HBsAg}<1000 \mathrm{IU} / \mathrm{mL}$ and HBV-DNA $<2000 \mathrm{IU} / \mathrm{mL}$ can identify a 3-year inactive state in a genotype D HBeAg-negative carrier population. In the Asian-Pacific region, where HBV genotypes B and C are dominant, HBsAg levels of $\leq 10-100 \mathrm{IU} / \mathrm{mL}$ predict HBsAg loss over time. As to the prediction of disease progression, low-viremic carriers with $\mathrm{HBsAg}>1000 \mathrm{IU} / \mathrm{mL}$ have been shown to be at higher risks of HBeAg-negative hepatitis, cirrhosis, and hepatocellular carcinoma than those with $\mathrm{HBsAg}<1000 \mathrm{IU} / \mathrm{mL}$. Although qHBsAg has been widely used in CHB patients receiving pegylated interferon therapy, the HBsAg decline is slow and does not correlate with HBV-DNA levels during nucleos(t)ide analogue (NUC) therapy. However, a rapid HBsAg decline during NUC therapy may identify patients who will finally clear HBsAg. A 6- to 12-monthly assessment of HBsAg level could be considered during NUC therapy. Taking these lines of evidence together, qHBsAg can complement HBV-DNA levels to optimize the management of CHB patients in our daily clinical practice.

Keywords $\mathrm{qHBsAg} \cdot \mathrm{HCC} \cdot \mathrm{NUC} \cdot \mathrm{HBV}$

\section{Introduction}

Although safe and effective vaccines have been available for nearly 3 decades, hepatitis B virus (HBV) infection is still an important public health problem. The clinical manifestations of HBV infection range from acute or fulminant hepatitis to various forms of chronic infection, including an inactive carrier state, chronic hepatitis, cirrhosis, and hepatocellular carcinoma (HCC) [1]. Hepatitis B surface antigen (HBsAg) is the hallmark of $\mathrm{HBV}$ 
infection and was first discovered by Blumberg and his colleagues, reported in 1968 [2]. Since then, HBsAg has been used as a marker for the diagnosis of HBV infection. Being a qualitative test, $\mathrm{HBsAg}$ has been used by most practicing physicians as one of the serological tests to determine the etiology of hepatitis but not to monitor disease progression in patients with chronic HBV infection. In clinical practice, physicians used to rely only on serological qualitative or semi-quantitative markers such as $\mathrm{HBsAg}$ and hepatitis $\mathrm{B}$ e antigen ( $\mathrm{HBeAg}$ ), as well as liver biochemical tests, to determine the disease phases of $\mathrm{HBV}$ carriers; however, since 2007, the quantification of serum HBV DNA level has become a useful marker to predict long-term outcomes of such patients [3]. The recent introduction of HBsAg quantification has attracted much attention for its value in being able to stratify the risk of disease progression and predict treatment response to antiviral therapy in patients with chronic HBV infection. In this review article, recent updates on reports of $\mathrm{HBsAg}$ level as a new biomarker to optimize the management of chronic hepatitis B will be discussed.

\section{Life cycle of HBV and synthesis of HBsAg}

Having only 3200 base pairs in its genome, HBV is the smallest known DNA virus. Figure 1 illustrates the pathway of HBsAg production in the life cycle of HBV. The replication template of HBV is covalently closed circular DNA (cccDNA), which exists in liver and encodes four overlapping open reading frames (ORFs): $\mathrm{S}$ for the surface gene, $\mathrm{C}$ for the core gene, $\mathrm{P}$ for the polymerase gene, and $\mathrm{X}$ for the $\mathrm{X}$ gene [4]. The $\mathrm{S}$ and $\mathrm{C}$ genes also have up-stream regions designated pre-S and pre-C. The whole virion, or Dane particle, is a $42 \mathrm{~nm}$ sphere that contains the nucleocapsid and relaxed circular HBV DNA. HBV DNA is synthesized via the reverse transcription of pregenomic RNA, which is also derived from cccDNA. Therefore, cccDNA is the template for both HBV DNA and HBsAg synthesis, while both products are derived from different ORFs of cccDNA (Fig. 1). HBsAg is a glycosylated envelope protein of $\mathrm{HBV}$ virions. There are $3 \mathrm{HBsAg}$ proteins - small (S), medium (M), and large (L), and they are translated from pre-S1 mRNA and pre-S2/S mRNA, which are transcribed from $\mathrm{S}$ gene of cccDNA. In addition to the HBsAg on the mature virions, there are large numbers of 2 types of non-infectious particles in the sera of HBV carriers: spherical particles and filamentous forms (Fig. 1). Both types of non-infectious subviral particles are composed of HBsAg. The subviral particles do not contain the HBV genome but are secreted at levels far in excess (100-100000 folds) of those of mature virions. Meanwhile, HBsAg can also be synthesized from viral sequences that are integrated randomly into the host genome. Virologically, quantification of serum HBV DNA merely reflects viral replication activity; however, serum HBsAg is produced not only from translated messenger RNAs of transcriptionally active cccDNA but also from integrated HBV DNA sequences. Thus, compared with HBV DNA level, HBsAg level provides different but complementary information that may help us understand patients' infection status more comprehensively.

As to other viral proteins, hepatitis B core antigen ( $\mathrm{HBcAg}$ ) is the nucleocapsid that encloses the viral DNA. When peptides derived from HBcAg and possibly others, such as surface and polymerase proteins, are processed and expressed on the surfaces of liver cells, apoptosis or necrosis of $\mathrm{HBV}$-infected hepatocytes may develop and the virus could be cleared [5].

$\mathrm{HBeAg}$ is a circulating peptide derived from the core gene, then modified and secreted from liver cells. It usually
Fig. 1 Pathway of hepatitis B surface antigen $(H B s A g)$ production in the life cycle of hepatitis B virus $(H B V)$ replication. $c c c D N A$ covalently closed circular DNA, ER endoplasmic reticulum, PreS2/S mRNA, Pre-S1 mRNA. Adapted from J Hepatol. 2011;55:1121-31

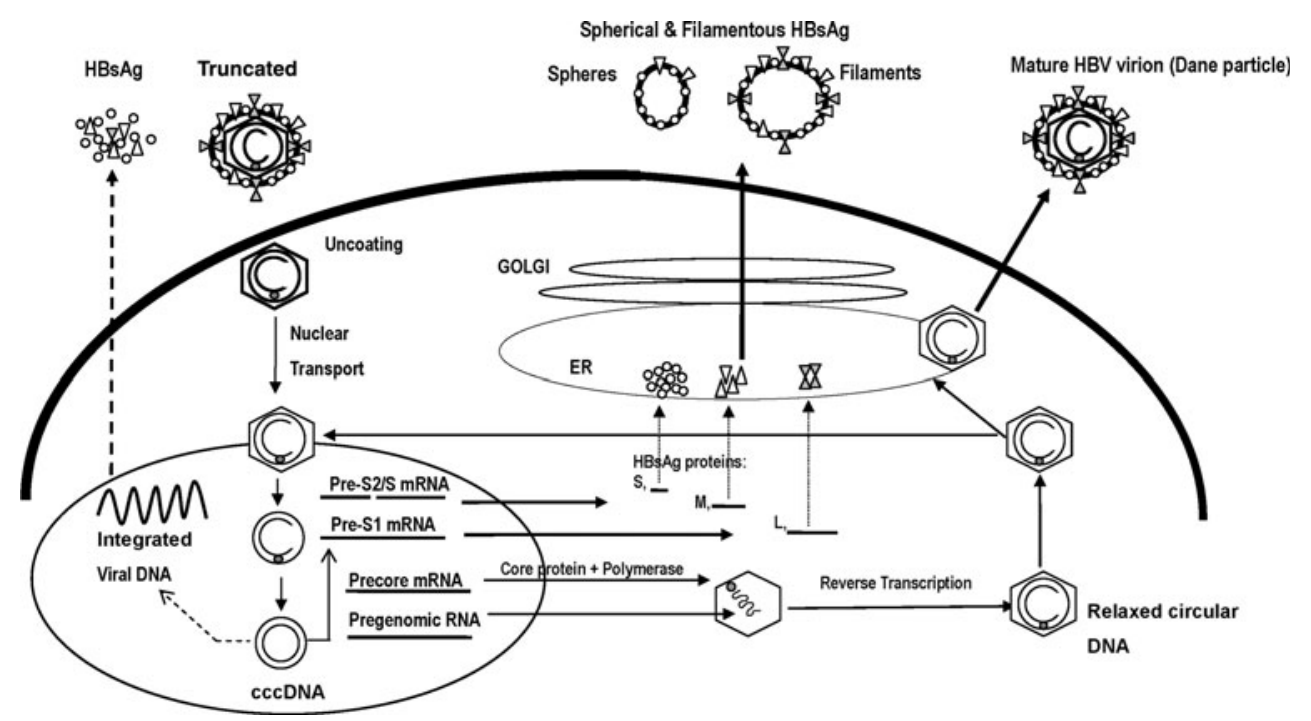


serves as a marker of active viral replication. The long $\mathrm{P}$ gene encodes the DNA polymerase; however, because viral replication requires RNA intermediates, the polymerase also provides HBV's reverse transcription function. The $\mathrm{X}$ gene encodes the protein that has transactivation activities on the HBV enhancer in aiding viral replication. The $\mathrm{X}$ protein can also transactivate other cellular genes that may play a part in hepatocarcinogenesis [5].

\section{Natural history of chronic hepatitis B}

In Asia, where $\mathrm{HBV}$ infection is hyperendemic, HBV carriers usually acquire the virus perinatally or in early childhood by the age of 2 years; therefore, the age of a given patient can be considered as the duration of infection. On the basis of interactions between virus and host, the natural course of Asian patients with chronic HBV infection can be divided into four chronological phases [6, 7] (Fig. 2). The first is the "immune tolerance phase", which is characterized by active replication of $\mathrm{HBV}$, positivity for HBeAg, and normal-to-low alanine aminotransferase (ALT) levels. The second is the "immune clearance phase", where HBeAg-positive patients have raised ALT levels and a decline of HBV DNA level. In the third "low replication or residual phase", patients lose $\mathrm{HBeAg}$ and gain antibody to $\mathrm{HBeAg}$ (anti-HBe) with remission of liver disease and are designated as being in an "inactive carrier state". HBeAg seroconversion (losing HBeAg and gaining anti-HBe) is a critical landmark event in the natural history of chronic HBV infection because it usually confers a favorable clinical outcome [8]. However, about 20-30\% of inactive carriers may enter a "reactivation or $\mathrm{HBeAg}$ negative hepatitis phase" during follow-up, which is now recognized as a variant of the immune clearance phase [9-11]. Previous longitudinal studies have indicated that HBeAg-negative hepatitis is a major risk factor for subsequent cirrhosis and HCC development [9, 12-14]. Therefore, early identification of at-risk patients and prompt antiviral treatment are mandatory to prevent or reduce disease progression. In the meantime, there also exist chances for $\mathrm{HBV}$ carriers to have HBsAg seroclearance or seroconversion, which is closest to the cure for HBV infection [15].

\section{HBsAg and HBV DNA levels in different phases of chronic hepatitis $B$}

Several cross-sectional studies have compared HBV DNA and HBsAg levels among different phases of chronic hepatitis B (Fig. 2) [16-18]. Although the study populations and $\mathrm{HBV}$ genotypes are different, the study results are comparable. Both HBsAg and HBV DNA levels vary at different phases of HBV infection but gradually decrease as HBV carriers become older. The levels are highest in the initial immune tolerance phase when serum ALT level is normal with no or minimal hepatitis activity. The levels become lower during the immune clearance phase and persistently decrease in those who maintain normal ALT levels after $\mathrm{HBeAg}$ seroconversion. All the above reports have indicated that the lowest levels of HBsAg and HBV
Fig. 2 HBsAg levels in different phases of chronic HBV infection. $H B e A g$ hepatitis $\mathrm{B}$ e antigen, $C H B$ chronic hepatitis $\mathrm{B}, A L T$ alanine aminotransferase, Anti-HBe $\mathrm{HBe}$ antibody

\begin{tabular}{|c|c|c|c|c|c|}
\hline & $\begin{array}{l}\text { Immune } \\
\text { tolerance }\end{array}$ & $\begin{array}{l}\text { Immune clearance } \\
\left(\mathrm{HBeAg}^{+} \mathrm{CHB}\right)\end{array}$ & $\begin{array}{l}\text { Low replication } \\
\text { (inactive carrier) }\end{array}$ & $\begin{array}{l}\text { Reactivation } \\
\left.\mathrm{HBeAg}^{-} \mathrm{CHB}\right)\end{array}$ & Reference \\
\hline \multirow[t]{3}{*}{ Sero-status } & & & & & \\
\hline & \multicolumn{3}{|l|}{$\mathrm{HBeAg}$} & Anti-HBe & \\
\hline & \multicolumn{2}{|c|}{ HBeAg-positive } & $\begin{array}{l}\mathrm{HBeAg}- \\
\text { negative }\end{array}$ & $\begin{array}{l}\mathrm{HBeAg}- \\
\text { negative }\end{array}$ & \\
\hline \multicolumn{6}{|l|}{ ALT level } \\
\hline \multicolumn{6}{|l|}{ HBV DNA level } \\
\hline \multirow{3}{*}{$\begin{array}{l}\text { HBsAg level } \\
(\log 10 \mathrm{IU} / \mathrm{mL})\end{array}$} & 5.0 & $3.0-4.0$ & $1.5-2.2$ & $2.5-3.0$ & 16 \\
\hline & 5.0 & 4.4 & 3.1 & 4.0 & 17 \\
\hline & 4.5 & 4.0 & 2.9 & 3.4 & 18 \\
\hline \multirow{3}{*}{$\begin{array}{l}\text { HBV DNA level } \\
\text { (log10 IU/mL) }\end{array}$} & $7.5-8.5$ & $6.0-7.0$ & $1.0-2.4$ & $3.9-4.6$ & 16 \\
\hline & 8.0 & 7.5 & 2.5 & 5.5 & 17 \\
\hline & 8.2 & 8.0 & $<2.6$ & 5.0 & 18 \\
\hline
\end{tabular}


DNA occur in the inactive carrier state but that the levels are higher in the reactivation phase or $\mathrm{HBeAg}$-negative hepatitis stage.

\section{Predictive values of HBsAg and HBV DNA in clinical outcomes of chronic hepatitis $B$ infection}

Considering long-term outcomes of patients with chronic HBV infection, favorable outcomes include an inactive carrier state and loss of HBsAg, whereas adverse outcomes include HBeAg-negative hepatitis, cirrhosis and HCC.

Brunetto et al. [19] first studied whether serum HBsAg levels may contribute to diagnosis of clinical stages in HBeAg-negative HBV carriers with genotype D infection. They analyzed 209 untreated and asymptomatic carriers in Italy and found the combination of single-point quantification of HBsAg $(<1000 \mathrm{IU} / \mathrm{mL})$ and HBV-DNA $(<2000 \mathrm{IU} / \mathrm{mL})$ could identify a 3-year inactive state with $94.3 \%$ diagnostic accuracy, $91.1 \%$ sensitivity, $95.4 \%$ specificity, $87.9 \%$ positive predictive value, and $96.7 \%$ negative predictive value. Our recent study also confirmed that a combination of HBsAg $(<1000 \mathrm{IU} / \mathrm{mL})$, normal serum ALT level, and HBV-DNA $(<2000 \mathrm{IU} / \mathrm{mL})$ could identify minimal-risk HBV carriers in Taiwanese patients with HBV genotype B or C infection (Hepatology, doi: 10.1002/hep.26041).

It is widely accepted that spontaneous clearance of HBsAg correlates with better clinical outcomes because it usually indicates disease remission [15, 20-23]. As long as there is no evidence of liver cirrhosis or HCV/HDV superinfection, and as long as the subject's age is $<50$ years at the time of HBsAg loss, there is a minimal risk of HCC development [20]. Previous longitudinal studies have indicated that the annual rate of HBsAg loss is approximately $0.4-2.3 \%$, depending on the subject's age and status of liver disease at enrolment [24-30]. However, it usually needs a large-scale cohort study with a long-term follow-up to address this issue of HBsAg loss because of its low incidence rate.

Earlier studies suggested that the HBsAg loss rate was lowest in HBeAg-positive patients, followed by that in patients with $\mathrm{HBeAg-negative} \mathrm{hepatitis,} \mathrm{with} \mathrm{the} \mathrm{loss} \mathrm{rate}$ being highest in inactive carriers [15]. In a longitudinal study from Taiwan, in which a total of 1965 HBeAg-negative patients with normal ALT levels were enrolled, Chu et al. [25] reported an annual HBsAg loss rate of $1.15 \%$. They found that HBeAg-negative patients with sustained normal ALT levels were more likely to clear HBsAg than those with hepatitis relapse. Subsequently, a communitybased large cohort study, Risk Evaluation of Viral Load Elevation and Associated Liver Disease/Cancer-Hepatitis B Virus (REVEAL-HBV), further demonstrated that a lower HBV DNA level was the major predictor of HBsAg loss over time [28]. In adult patients with an undetectable viral load $(<60 \mathrm{IU} / \mathrm{mL})$, the annual rate of HBsAg loss was $5.76 \%$. Compared with patients with an HBV DNA level of $\geq 200000 \mathrm{IU} / \mathrm{mL}$, the hazard ratio (HR) of HBsAg loss was 15.9 [95\% confidence interval (CI) 9.3-27.2]. Because patients with low viral loads usually have a low risk of hepatitis relapse, the association between a limited viral replication and a higher chance of HBsAg loss could explain why HBsAg loss occurs more frequently in patients with persistently normal ALT levels.

Our hospital-based cohort study, Study of E Antigen seRoClearance of Hepatitis B patients (SEARCH-B), enrolled 390 spontaneous $\mathrm{HBeAg}$ seroconverters and highlighted the impact of the HBsAg level at 1 year post$\mathrm{HBeAg}$ seroconversion on subsequent HBsAg loss [29]. During an average follow-up period of 7.4 years, 18 patients cleared HBsAg, with an annual rate of $0.6 \%$. It was found that HBsAg level, compared with HBV DNA level, served as a better predictor of HBsAg loss. Even in patients with an HBV DNA level of $<200 \mathrm{IU} / \mathrm{mL}$ at 1 year post-HBeAg seroconversion, an $\mathrm{HBsAg}$ level of $<100 \mathrm{IU} / \mathrm{mL}$ remained an independent predictor of $\mathrm{HBsAg}$ loss. Although this study shed light on the importance of HBsAg level, the statistical power was not strong enough to fully address the relationship between HBsAg level and HBsAg loss. We therefore conducted another hospitalbased cohort study, Elucidation of Risk fActors for DIsease Control or Advancement in Taiwanese hEpatitis B carriers (ERADICATE-B), and enrolled 2688 patients with chronic hepatitis B infection. We analyzed the data of $688 \mathrm{HBeAg}$ negative patients who had HBV DNA level $<2000 \mathrm{IU} / \mathrm{mL}$ at baseline and were enrolled in the earlier stage of the study [30]. During a mean follow up of 11.6 years, 130 patients cleared HBsAg, with an annual rate of $1.6 \%$. We consistently found that HBsAg level, compared with HBV DNA level, served as a better predictor of HBsAg loss. In addition, the annual clearance rate of $\mathrm{HBsAg}$ reached $7 \%$ in patients with an HBsAg level of $<10 \mathrm{IU} / \mathrm{mL}$ [HR of 13.2 (95\% CI 8.1-21.5) when compared with an HBsAg level of $\geq 1000 \mathrm{IU} / \mathrm{mL}$. This large-scale study firmly confirmed the importance of HBsAg level on the development of HBsAg loss.

In addition to these cohorts, several other studies have also validated the relationship between HBsAg level and HBsAg loss (Table 1). A cohort study and a case-control study from Hong Kong showed a very similar trend: a lower HBsAg level was associated with a higher chance of HBsAg loss; HBsAg levels of 100 and $200 \mathrm{IU} / \mathrm{mL}$, respectively, were their recommended cutoffs [31, 32]. Other studies from Taiwan, including the REVEAL-HBV cohort study, a pediatric cohort study, and a case-control study, all had very similar findings [33-35]. Although the 
Table 1 Relationship between hepatitis B antigen (HBsAg) level and HBsAg loss in the literature

\begin{tabular}{|c|c|c|c|c|c|c|}
\hline Country & $\begin{array}{l}\text { Study } \\
\text { design }\end{array}$ & Disease stage & $\begin{array}{l}\text { Number } \\
\text { of subjects }\end{array}$ & $\begin{array}{l}\text { HBsAg cutoff } \\
\text { (IU/mL) }\end{array}$ & Note & Reference \\
\hline Taiwan & Cohort & Early $\mathrm{HBeAg}$-negative stage & 390 & 100 & SEARCH-B & [29] \\
\hline Hong Kong & Cohort & $\mathrm{HBeAg}$-negative & 103 & 100 & & {$[32]$} \\
\hline Taiwan & Cohort & $\begin{array}{l}\text { HBeAg-negative with } \\
\text { hepatitis B virus }(\mathrm{HBV}) \\
\text { DNA level }<2000 \mathrm{IU} / \mathrm{mL}\end{array}$ & 688 & 10 & ERADICATE-B (partial) & {$[30]$} \\
\hline Taiwan & Case-control & HBeAg-negative & $46-46$ & 200 & & {$[35]$} \\
\hline Hong Kong & Case-control & $\mathrm{HBe} A g$-negative & $203-203$ & 200 & & {$[31]$} \\
\hline Taiwan & Cohort & Children & 349 & 1000 & & {$[34]$} \\
\hline Taiwan & Cohort & $\begin{array}{l}\text { Including } \mathrm{HBeAg} \text {-positive } \\
\text { and -negative }\end{array}$ & 3466 & 10 & REVEAL-HBV & {$[33]$} \\
\hline
\end{tabular}

recommended cutoffs varied among the different study populations, all these studies pointed to the main finding that a lower HBsAg level was closely associated with a higher likelihood of HBsAg loss over time.

As to the prediction of disease progression, most longitudinal cohort studies have already agreed that chronic hepatitis, cirrhosis, and HCC are sequential complications of chronic hepatitis B infection [9, 12-14] and HCC is the most deadly one. Therefore, all the investigators were looking for the key factors affecting disease progression. The REVEAL-HBV study is the first cohort study to disclose that the serum HBV DNA level is a major driving force of adverse clinical outcomes [3, 36]; the authors of that study found that a higher HBV DNA level was associated with both cirrhosis and HCC development, with a dose-response relationship in adult HBV carriers. In addition, the risk started to increase when patients had HBV DNA levels of $\geq 2000 \mathrm{IU} / \mathrm{mL}$. This important finding established the HBV DNA threshold level of $2000 \mathrm{IU} / \mathrm{mL}$ for treating HBV carriers and the use of a level of $<2000 \mathrm{IU} / \mathrm{mL}$ for defining inactive HBV carriers [37-39].

When the assay of HBsAg quantification became available, the association between HBsAg level and HCC was firstly revealed by the ERADICATE-B cohort [40]. This cohort included 2688 Taiwanese HBV carriers who had no evidence of cirrhosis at baseline and were treatment-free during the follow-up period. At the beginning, the study demonstrated that both HBV DNA and HBsAg levels positively correlated with HCC development. When these two biomarkers were compared in predicting HCC, HBV DNA level served as a better predictor in the overall cohort. However, when the study population was limited to $1068 \mathrm{HBeAg}$-negative patients with an HBV DNA level of $<2000 \mathrm{IU} / \mathrm{mL}$, in whom HBV DNA level has little impact in predicting $\mathrm{HCC}, \mathrm{HBsAg}$ level remained the only viral risk factor. More specifically, in HBeAg-negative patients with an HBV DNA level of $<2000 \mathrm{IU} / \mathrm{mL}$, there was an increased HCC risk for an HBsAg level of $\geq 1000$ versus $<1000 \mathrm{IU} / \mathrm{mL}$ with an HR of 5.4 (95 \% CI 2.1-14.2). The 10-year cumulative incidence rate of $\mathrm{HCC}$ was $0.2 \%$ for HBeAg-negative patients with an HBV DNA level of $<2000 \mathrm{IU} / \mathrm{mL}$ plus an HBsAg level of $<1000 \mathrm{IU} / \mathrm{mL}$, and this rate was similar to the rate of non-HBV and non-HCV infected patients [41].

It is generally believed that cirrhosis usually results from an accumulation of extracellular matrix arising from liver cell injury, and HCC may subsequently emerge in the setting of cirrhosis [7, 9, 11-14]. If the correlation between HBsAg level and HCC is true, it is expected to exist consistent relationships between $\mathrm{HBsAg}$ level and HBeAgnegative hepatitis as well as cirrhosis development. On the basis of this hypothesis, we analyzed the $1068 \mathrm{HBeAg}$ negative patients with low viral loads from the ERADICATE-B study. An HBsAg level of $\geq 1000 \mathrm{IU} / \mathrm{mL}$ was noted to be consistently associated with a higher risk of HBeAg-negative hepatitis and cirrhosis. As opposed to an HBsAg level of $<1000 \mathrm{IU} / \mathrm{mL}$, the $\mathrm{HR}$ of $\mathrm{HBsAg}$ $\geq 1000 \mathrm{IU} / \mathrm{mL}$ was $1.4(95 \% \mathrm{CI} 1.1-1.8)$ for HBeAgnegative hepatitis and 2.2 (95\% CI 1.1-4.2) for cirrhosis development (Hepatology, doi:10.1002/hep.26041).

Taking all these lines of evidence together, combining HBV DNA and HBsAg levels could be used to define "minimal-risk" patients with chronic HBV infection. The term "inactive carrier" was not used in our serial studies, because its operational criteria included persistently low levels of ALT and HBV DNA, which are very unlikely to be used in a large-scale cohort study. With snapshot HBV DNA and HBsAg levels, it is possible to identify patients with minimal risk of disease progression in our daily clinical practice. In fact, the REVEAL-HBV cohort study also reported a finding very similar to that of the ERADICATE-B cohort study: a lower HBsAg level in patients with an HBV DNA level of $<2000 \mathrm{IU} / \mathrm{mL}$ was associated with a lower risk of HCC [42]. On the basis of these data, it 
is believed that HBsAg level helps predict the prognosis of HBV carriers; however, the following issues need to be addressed. First, the appropriate HBsAg cutoff level needs further examination. Second, most of the data have come from Asia, and it is unclear whether this finding holds true in Western countries where genotypes A and D prevail and most patients acquire the infection later in life. If more lines of evidence can confirm the predictive value of HBsAg, HBsAg level should be included in the future development of a risk calculator or nomogram for $\mathrm{HBV}$ carriers and treatment guidelines for chronic hepatitis $\mathrm{B}$ $[43,44]$.

\section{Decline of HBsAg in natural history of $\mathrm{HBV}$ infection}

In the natural history of chronic HBV infection, declines of HBV DNA and HBsAg levels are important milestones towards good prognosis $[40,45]$. Compared to the fluctuation of HBV DNA level and its remarkable decline after $\mathrm{HBeAg}$ seroconversion [29], HBsAg level is more stable and the decline in HBsAg level is usually slow [16, 29]. The REVEAL-HBV study indicated that HBsAg loss was preceded by seroclearance of HBV DNA [28]. A recent study from Hong Kong also showed that patients with an undetectable HBV DNA level had a more pronounced reduction of HBsAg levels than those with high HBV DNA levels [46]. Therefore, although the levels of both markers decrease over time, the seroclearance of HBV DNA usually precedes a prominent reduction of HBsAg level. In addition, previous studies have reported that reductions of HBsAg by $1 \log \mathrm{IU} / \mathrm{mL}$ [16] and $0.5 \log \mathrm{IU} / \mathrm{mL}$ [31] are associated with a higher chance of HBsAg loss. Taken together, these findings suggest that a rapid reduction of HBsAg usually follows the seroclearance of HBV DNA and that such a reduction of HBsAg may lead to a higher likelihood of HBsAg loss.

Of particular note is that all these longitudinal studies are coming from Asian countries. Whether these observations hold true for Western patients warrants more studies.

\section{Clinical significance of quantitative HBsAg in chronic hepatitis $B$ patients with antiviral therapy}

Table 2 shows current treatment strategies for chronic hepatitis B [47]. The therapeutic endpoints for chronic hepatitis B include sustained suppression of HBV DNA level, normalization of serum ALT level, histologic improvement, $\mathrm{HBeAg}$ loss or seroconversion for $\mathrm{HBeAg}$ positive patients, and, ideally, HBsAg loss or seroconversion [37-39]. Nowadays, seven approved agents for the treatment of chronic hepatitis B are as follows. Standard or pegylated interferon alpha (IFN or Peg-IFN) and five nucleos(t)ide analogues (NUCs)-lamivudine, telbivudine, entecavir, adefovir dipivoxil, and tenofovir disoproxil furamate. Although we have different agents in clinical practice, there are only two treatment strategies, immune control (sustained off-therapy response) and viral control (maintained on-treatment response).

\section{qHBsAg and Peg-IFN therapy}

qHBsAg and Peg-IFN therapy has been comprehensively reviewed elsewhere [48, 49]. In brief, on Peg-IFN treatment, sustained responders tend to show a greater HBsAg decline than non-responders. The optimal on-treatment HBsAg cutoff to predict response in $\mathrm{HBeAg}$-positive patients may be $20000 \mathrm{IU} / \mathrm{ml}$ at week 12 or 24 of therapy $[50,51]$; however, determination of the cutoff needs further evaluation by prospective studies. In contrast, an absence of $\mathrm{HBsAg}$ decline together with a $<2 \log$ reduction in HBV DNA at week 12 can serve as a futility rule in HBeAg-negative patients with HBV genotype D infection $[52,53]$.

\section{qHBsAg and NUC therapy}

The decline of HBsAg during NUC therapy is less pronounced than that during Peg-IFN therapy [54]. In patients receiving NUCs, the decline of $\mathrm{HBsAg}$ appears more apparent in $\mathrm{HBeAg}$-positive patients than in HBeAg-negative patients [55]. Two large-scale clinical trials have shown that the reduction of HBsAg is pronounced within the first year of telbivudine or tenofovir treatment, and that HBsAg level remains relatively stable thereafter $[55,56]$. For HBeAg-negative patients, HBsAg level does not vary significantly during NUC therapy [55]. Other studies had similar results [57-59]. Two observational studies including $\mathrm{HBeAg}$-positive patients with entecavir therapy indicated that patients with $\mathrm{HBeAg}$ loss/seroconversion had an early decline of $\mathrm{HBsAg}$ levels, while those without $\mathrm{HBeAg}$ loss/seroconversion did not [57, 59]. Although the mechanism of HBsAg decline during NUC therapy is unclear, it may be hypothesized that the reduction of HBsAg level reflects a better degree of host immune control against the virus or even a decrease in the amount of intrahepatic cccDNA. From a conceptual viewpoint, it is known that NUC only blocks the reverse transcriptase, which diminishes HBV DNA synthesis but lacks a direct effect on cccDNA. Therefore, the observation that Peg-IFN produces a more pronounced HBsAg decline than NUCs do is reasonable, because Peg-IFN can induce apoptosis or necrosis in $\mathrm{HBV}$-infected hepatocytes. On the other hand, the early 
Table 2 Current treatment strategies for chronic hepatitis B

\begin{tabular}{|c|c|c|c|c|}
\hline Treatment & Strategy & Goal & Duration & Effectiveness \\
\hline $\begin{array}{l}\text { Standard or pegylated } \\
\text { interferon alfa }\end{array}$ & $\begin{array}{l}\text { Sustained off- } \\
\text { therapy } \\
\text { response } \\
\text { (immune } \\
\text { control) }\end{array}$ & $\begin{array}{l}\text { Low HBV DNA level } \\
(<2000 \mathrm{IU} / \mathrm{mL}) \text { and normal } \\
\text { alanine aminotransferase } \\
\text { (ALT) level }\end{array}$ & Finite & $\begin{array}{l}\text { Sustained response in } \sim 30 \% \text { of patients after } \\
48 \text { weeks of therapy, and may increase to } \\
50 \% \text { in those with good baseline and on- } \\
\text { treatment factors }\end{array}$ \\
\hline $\begin{array}{l}\text { Nucleos }(\mathrm{t}) \text { ide analogues } \\
\text { (lamivudine, adefovir, } \\
\text { telbivudine, entecavir, or } \\
\text { tenofovir) }\end{array}$ & $\begin{array}{l}\text { Maintained on- } \\
\text { treatment } \\
\text { response (viral } \\
\text { control) }\end{array}$ & $\begin{array}{l}\text { Undetectable HBV DNA } \\
\text { level and normal ALT }\end{array}$ & $\begin{array}{l}\text { Prolonged } \\
\text { or } \\
\text { indefinite }\end{array}$ & $\begin{array}{l}\text { Successful suppression of HBV DNA with } \\
\text { continued treatment without drug resistance }\end{array}$ \\
\hline
\end{tabular}

decline of HBsAg in patients receiving NUCs may be attributed to the restoration of the host immune response against HBV as reflected by the pretreatment ALT level. Thus, when the effect of the immune reaction diminishes, such as during the second or third year of NUC treatment, the decline of HBsAg would be less significant. However, this speculation does not totally exclude the utility of NUCs to lower HBsAg level. As we have learned the lessons from the natural history of $\mathrm{HBV}$ infection, achieving undetectable HBV DNA is essential for lowering the HBsAg level or even for clearing HBsAg and NUCs are characterized by their ability to inhibit HBV DNA synthesis to a very low or undetectable level. Furthermore, most studies of NUCs included patients who had been receiving the treatment for less than 5 years. Therefore, it is premature to conclude that NUCs fail to significantly reduce $\mathrm{HBsAg}$ levels over time.

HBsAg loss has been reported during NUC therapy in HBeAg-positive patients. In $\mathrm{HBeAg}$-positive patients treated with tenofovir, the rates of HBsAg loss were 3, 6 , and $8 \%$ after 1,2 , and 3 years of therapy, respectively. Nevertheless, HBsAg loss was not observed in HBeAgnegative patients [55]. The HBsAg loss rates for $\mathrm{HBeAg}$ positive patients treated with entecavir or lamivudine for 2 years were 5 and $3 \%$, respectively [60]. For $\mathrm{HBeAg}-$ positive patients receiving telbivudine and tenofovir therapy, a rapid decline of the HBsAg level during the first year of therapy was associated with a higher probability of HBsAg loss [56, 61]. Of note, the correlation between HBsAg decline and HBsAg loss in NUC users is in line with what we have observed in the natural history: the greater the decline of HBsAg, the higher is the chance of spontaneous HBsAg loss. However, most patients with NUC-induced HBsAg loss have HBV genotype A or D infection [55, 56, 60], and the clearance of HBsAg by NUCs seems very rare in Asian patients with genotype B or $\mathrm{C}$ infection. In other words, it may not be practical to consider HBsAg loss as the therapeutic endpoint for Asian HBV carriers. Our recent data derived from the investigation of HBV's natural history has shown that an HBsAg level of $<1000 \mathrm{IU} / \mathrm{mL}$ plus an HBV DNA level of
$<2000 \mathrm{IU} / \mathrm{mL}$ may determine minimal-risk HBV carriers [40]. In future, we should evaluate whether a lower HBsAg level, say $<1000 \mathrm{IU} / \mathrm{mL}$ at the end of NUC therapy, could serve as a therapeutic endpoint for such patients with HBV genotype $\mathrm{B}$ or $\mathrm{C}$ infection.

\section{Perspectives and conclusions}

Although we have understood more about the clinical utility of quantitative $\mathrm{HBsAg}$ in the management of patients with chronic HBV infection in the past years, there still exist several unmet medical needs. First, we need more data, especially cohort studies from Western countries, to confirm the findings observed in Asian patients. More importantly, we need to determine an appropriate cutoff to define minimal-risk HBV carriers, depending on how high an HCC risk we can tolerate. Second, the role of the HBsAg level in predicting HCC risk in HBV carriers with intermediate viral loads (between 2000 and $20000 \mathrm{IU} / \mathrm{mL}$ ) remains to be explored. Third, the usefulness of combining HBsAg and HBV DNA levels for the risk stratification of HBeAg-negative disease needs further examination. Finally, more prospective studies are awaited to evaluate the impact of baseline and on-treatment HBsAg levels on the identification of responders and non-responders in patients receiving anti-HBV therapy, especially NUC therapy.

Conflict of interest J.H. Kao is a member of the speaker's bureau for Roche, BMS, Gilead, Novartis, and Bayer, and has received a grant from BMS. T.C. Tseng declares no potential conflicts of interest.

\section{References}

1. Kao JH, Chen PJ, Chen DS. Recent advances in the research of hepatitis B virus-related hepatocellular carcinoma: epidemiologic and molecular biological aspects. Adv Cancer Res. 2010;108:21-72.

2. Blumberg BS, Sutnick AI, London WT. Hepatitis and leukemia: their relation to Australia antigen. Bull N Y Acad Med. 1968;44:1566-86. 
3. Chen CJ, Yang HI, Su J, Jen CL, You SL, Lu SN, et al. Risk of hepatocellular carcinoma across a biological gradient of serum hepatitis B virus DNA level. JAMA. 2006;295:65-73.

4. Kao JH, Chen DS. Global control of hepatitis B virus infection. Lancet Infect Dis. 2002;2:395-403.

5. Dandri M, Locarnini S. New insight in the pathobiology of hepatitis B virus infection. Gut. 2012;61(Suppl 1):i6-17.

6. Chen DS. From hepatitis to hepatoma: lessons from type B viral hepatitis. Science. 1993;262:369-70.

7. Liaw YF, Chu CM. Hepatitis B virus infection. Lancet. 2009;373:582-92.

8. Liaw YF, Lau GK, Kao JH, Gane E. Hepatitis B e antigen seroconversion: a critical event in chronic hepatitis B virus infection. Dig Dis Sci. 2010;55:2727-34.

9. Chu CM, Liaw YF. Predictive factors for reactivation of hepatitis $\mathrm{B}$ following hepatitis $\mathrm{B}$ e antigen seroconversion in chronic hepatitis B. Gastroenterology. 2007;133:1458-65.

10. Chen YC, Chu CM, Liaw YF. Age-specific prognosis following spontaneous hepatitis $\mathrm{B}$ e antigen seroconversion in chronic hepatitis B. Hepatology. 2010;51:435-44.

11. Tseng TC, Liu CJ, Chen CL, Wang CC, Su TH, Kuo SF, et al. Serum hepatitis B virus-DNA levels correlate with long-term adverse outcomes in spontaneous hepatitis B e antigen seroconverters. J Infect Dis. 2012;205:54-63.

12. Hsu YS, Chien RN, Yeh CT, Sheen IS, Chiou HY, Chu CM, et al. Long-term outcome after spontaneous HBeAg seroconversion in patients with chronic hepatitis B. Hepatology. 2002;35:1522-7.

13. Tai DI, Lin SM, Sheen IS, Chu CM, Lin DY, Liaw YF. Longterm outcome of hepatitis B e antigen-negative hepatitis B surface antigen carriers in relation to changes of alanine aminotransferase levels over time. Hepatology. 2009;49:1859-67.

14. Chu CM, Hung SJ, Lin J, Tai DI, Liaw YF. Natural history of hepatitis $\mathrm{B}$ e antigen to antibody seroconversion in patients with normal serum aminotransferase levels. Am J Med. 2004;116: 829-34.

15. Chu CM, Liaw YF. Hepatitis B surface antigen seroclearance during chronic HBV infection. Antivir Ther. 2010;15:133-43.

16. Chan HL, Wong VW, Wong GL, Tse CH, Chan HY, Sung JJ. A longitudinal study on the natural history of serum hepatitis B surface antigen changes in chronic hepatitis B. Hepatology. 2010;52:1232-41.

17. Nguyen T, Thompson AJ, Bowden S, Croagh C, Bell S, Desmond PV, et al. Hepatitis B surface antigen levels during the natural history of chronic hepatitis B: a perspective on Asia. J Hepatol. 2010;52:508-13.

18. Jaroszewicz J, Calle Serrano B, Wursthorn K, Deterding K, Schlue J, Raupach R, et al. Hepatitis B surface antigen (HBsAg) levels in the natural history of hepatitis B virus (HBV)-infection: a European perspective. J Hepatol. 2010;52:514-22.

19. Brunetto MR, Oliveri F, Colombatto P, Moriconi F, Ciccorossi P, Coco B, et al. Hepatitis B surface antigen serum levels help to distinguish active from inactive hepatitis $B$ virus genotype D carriers. Gastroenterology. 2010;139:483-90.

20. Chen YC, Sheen IS, Chu CM, Liaw YF. Prognosis following spontaneous HBsAg seroclearance in chronic hepatitis B patients with or without concurrent infection. Gastroenterology. 2002;123:1084-9.

21. Fattovich G, Giustina G, Sanchez-Tapias J, Quero C, Mas A, Olivotto PG, et al. Delayed clearance of serum HBsAg in compensated cirrhosis $\mathrm{B}$ : relation to interferon alpha therapy and disease prognosis. European concerted action on viral hepatitis (EUROHEP). Am J Gastroenterol. 1998;93:896-900.

22. Huo TI, Wu JC, Lee PC, Chau GY, Lui WY, Tsay SH, et al. Seroclearance of hepatitis B surface antigen in chronic carriers does not necessarily imply a good prognosis. Hepatology. 1998;28: 231-6.
23. Yuen MF, Wong DK, Sablon E, Tse E, Ng IO, Yuan HJ, et al. $\mathrm{HBsAg}$ seroclearance in chronic hepatitis B in the Chinese: virological, histological, and clinical aspects. Hepatology. 2004;39:1694-701.

24. Liaw YF, Sheen IS, Chen TJ, Chu CM, Pao CC. Incidence, determinants and significance of delayed clearance of serum HBsAg in chronic hepatitis B virus infection: a prospective study. Hepatology. 1991;13:627-31.

25. Chu CM, Liaw YF. HBsAg seroclearance in asymptomatic carriers of high endemic areas: appreciably high rates during a longterm follow-up. Hepatology. 2007;45:1187-92.

26. McMahon BJ, Holck P, Bulkow L, Snowball M. Serologic and clinical outcomes of 1536 Alaska Natives chronically infected with hepatitis B virus. Ann Intern Med. 2001;135:759-68.

27. Kim JH, Lee JH, Park SJ, Bae MH, Do Kim Y, Kim JK, et al. Factors associated with natural seroclearance of hepatitis B surface antigen and prognosis after seroclearance: a prospective follow-up study. Hepatogastroenterology. 2008;55:578-81.

28. Liu J, Yang HI, Lee MH, Lu SN, Jen CL, Wang LY, et al. Incidence and determinants of spontaneous hepatitis B surface antigen seroclearance: a community-based follow-up study. Gastroenterology. 2010;139:474-82.

29. Tseng TC, Liu CJ, Su TH, Wang CC, Chen CL, Chen PJ, et al. Serum hepatitis B surface antigen levels predict surface antigen loss in hepatitis B e antigen seroconverters. Gastroenterology. 2011;141(517-525):e2.

30. Tseng TC, Liu CJ, Yang HC, Su TH, Wang CC, Chen CL, et al. Determinants of spontaneous surface antigen loss in hepatitis B e antigen-negative patients with a low viral load. Hepatology. 2012;55:68-76.

31. Seto WK, Wong DK, Fung J, Hung IF, Fong DY, Yuen JC, et al. A large case-control study on the predictability of hepatitis B surface antigen ( $\mathrm{HBsAg}$ ) levels three years before $\mathrm{HBsAg}$ seroclearance. Hepatology. 2012;56:812-9.

32. Lik-Yuen Chan H, Lai-Hung Wong G, Tse CH, Chan HY, Wai-Sun Wong V. Viral determinants of hepatitis B surface antigen seroclearance in hepatitis B e antigen-negative chronic hepatitis B patients. J Infect Dis. 2011;204:408-14.

33. Liu J, Lee MH, Batrla-Utermann R, Jen CL, Iloeje U, Lu SN, et al. Quantitative hepatitis B surface antigen levels are significant independent predictors of HBV DNA and HBsAg seroclearance in chronic hepatitis B. Hepatology. 2011;54:Abstract 239.

34. Chang MH, Chiu YC, Wu JF, Lin CY, Ni YH, Chen HL, et al. Spontaneous clearance of hepatitis B surface antigen during the natural history of chronic hepatitis B virus infection. Hepatology. 2011;54:Abstract 731.

35. Chen YC, Jeng WJ, Chu CM, Liaw YF. Decreasing levels of HBsAg predict HBsAg seroclearance in patients with inactive chronic hepatitis B virus infection. Clin Gastroenterol Hepatol. 2012;10:297-302.

36. Iloeje UH, Yang HI, Su J, Jen CL, You SL, Chen CJ, et al. Predicting cirrhosis risk based on the level of circulating hepatitis B viral load. Gastroenterology. 2006;130:678-86.

37. Lok AS, McMahon BJ. Chronic hepatitis B: update 2009. Hepatology. 2009;50:661-2.

38. European Association for the Study of the Liver. EASL clinical practice guidelines: management of chronic hepatitis B virus infection. J Hepatol. 2012;57:167-85.

39. Liaw YF, Kao JH, Piratvisuth T, Chan HL, Chien RN, Liu CJ, et al. Asian-Pacific consensus statement on the management of chronic hepatitis B: a 2012 update. Hepatol Int. 2012;6:531-61.

40. Tseng TC, Liu CJ, Yang HC, Su TH, Wang CC, Chen CL, et al. High levels of hepatitis B surface antigen increase risk of hepatocellular carcinoma in patients with low HBV load. Gastroenterology. 2012;142(1140-1149):e3. 
41. Chen JD, Yang HI, Iloeje UH, You SL, Lu SN, Wang LY, et al. Carriers of inactive hepatitis B virus are still at risk for hepatocellular carcinoma and liver-related death. Gastroenterology. 2010;138:1747-54.

42. Chen CJ, Lee MH, Jessica L, Ricard B-U, Jen CL, Uchenna I, et al. Quantitative serum levels of hepatitis B virus DNA and surface antigen are independent risk predictors of hepatocellular carcinoma. Hepatology. 2011;54:Abstract 1095.

43. Yang HI, Sherman M, Su J, Chen PJ, Liaw YF, Iloeje UH, et al. Nomograms for risk of hepatocellular carcinoma in patients with chronic hepatitis B virus infection. J Clin Oncol. 2010;28: 2437-44.

44. Yang HI, Yuen MF, Chan HL, Han KH, Chen PJ, Kim DY, et al. Risk estimation for hepatocellular carcinoma in chronic hepatitis $\mathrm{B}$ (REACH-B): development and validation of a predictive score. Lancet Oncol. 2011;12:568-74.

45. Chen CF, Lee WC, Yang HI, Chang HC, Jen CL, Iloeje UH, et al. Changes in serum levels of HBV DNA and alanine aminotransferase determine risk for hepatocellular carcinoma. Gastroenterology. 2011;141:1240-8, 1248 e1-2.

46. Seto WT, Wong KH, Fung J, Hung FN, Yuen CH, Tong T, et al. Serum hepatitis B surface antigen ( $\mathrm{HBsAg})$ kinetics in hepatitis B e antigen (HBeAg)-negative chronic hepatitis B. Hepatol Int. 2012 (in press). doi:10.1007/s12072-012-9373-4.

47. Lin CL, Kao JH. Recent advances in the treatment of chronic hepatitis B. Expert Opin Pharmacother. 2011;12:2025-40.

48. Chan HL, Thompson A, Martinot-Peignoux M, Piratvisuth T, Cornberg M, Brunetto MR, et al. Hepatitis B surface antigen quantification: why and how to use it in 2011-a core group report. J Hepatol. 2011;55:1121-31.

49. Janssen HL, Sonneveld MJ, Brunetto MR. Quantification of serum hepatitis B surface antigen: is it useful for the management of chronic hepatitis B? Gut. 2012;61:641-5.

50. Liaw YF, Jia JD, Chan HL, Han KH, Tanwandee T, Chuang WL, et al. Shorter durations and lower doses of peginterferon alfa-2a are associated with inferior hepatitis $\mathrm{B}$ e antigen seroconversion rates in hepatitis B virus genotypes B or C. Hepatology. 2011;54:1591-9.

51. Piratvisuth T, Marcellin P, Popescu M, Kapprell HP, Rothe V, Lu ZM. Hepatitis B surface antigen: association with sustained response to peginterferon alfa-2a in hepatitis $\mathrm{B}$ e antigen-positive patients. Hepatol Int. 2012 (In press). doi:10.1007/s12072-011-9280-0.
52. Rijckborst V, Hansen BE, Cakaloglu Y, Ferenci P, Tabak F, Akdogan $\mathrm{M}$, et al. Early on-treatment prediction of response to peginterferon alfa-2a for HBeAg-negative chronic hepatitis B using HBsAg and HBV DNA levels. Hepatology. 2010;52: 454-61.

53. Rijckborst V, Hansen BE, Ferenci P, Brunetto MR, Tabak F, Cakaloglu Y, et al. Validation of a stopping rule at week 12 using $\mathrm{HBsAg}$ and HBV DNA for HBeAg-negative patients treated with peginterferon alfa-2a. J Hepatol. 2012;56:1006-11.

54. Su TH, Hsu CS, Chen CL, Liu CH, Huang YW, Tseng TC, et al. Serum hepatitis B surface antigen concentration correlates with HBV DNA level in patients with chronic hepatitis B. Antivir Ther. 2010;15:1133-9.

55. Heathcote EJ, Marcellin P, Buti M, Gane E, De Man RA, Krastev $Z$, et al. Three-year efficacy and safety of tenofovir disoproxil fumarate treatment for chronic hepatitis B. Gastroenterology. 2011;140:132-43.

56. Wursthorn K, Jung M, Riva A, Goodman ZD, Lopez P, Bao W, et al. Kinetics of hepatitis B surface antigen decline during 3 years of telbivudine treatment in hepatitis B e antigen-positive patients. Hepatology. 2010;52:1611-20.

57. Reijnders JG, Rijckborst V, Sonneveld MJ, Scherbeijn SM, Boucher CA, Hansen BE, et al. Kinetics of hepatitis B surface antigen differ between treatment with peginterferon and entecavir. J Hepatol. 2011;54:449-54.

58. Fung J, Lai CL, Young J, Wong DK, Yuen J, Seto WK, et al. Quantitative hepatitis B surface antigen levels in patients with chronic hepatitis B after 2 years of entecavir treatment. Am J Gastroenterol. 2011;106:1766-73.

59. Lee JM, Ahn SH, Kim HS, Park H, Chang HY, Kim do Y, et al. Quantitative hepatitis B surface antigen and hepatitis B e antigen titers in prediction of treatment response to entecavir. Hepatology. 2011;53:1486-93.

60. Gish RG, Chang TT, Lai CL, de Man R, Gadano A, Poordad F, et al. Loss of HBsAg antigen during treatment with entecavir or lamivudine in nucleoside-naive $\mathrm{HBeAg}$-positive patients with chronic hepatitis B. J Viral Hepat. 2010;17:16-22.

61. Gane E, Heathcote EJ, Marcellin P, Dusheiko G, Jacobson I, de Man R, et al. HBsAg kinetics of decay and baseline characteristics of HBsAg-positive patients with chronic hepatitis B following 3 years of tenofovir disoproxil fumarate (TDF) treatment. J Hepatol. 2010;52(Suppl 1):S388. 